\title{
PEMANFAATAN Typha angustifolia DAN FUNGI MIKORIZA ARBUSKULAR UNTUK FITOREMEDIASI AIR ASAM TAMBANG
}

\section{Utilization of Typha angustifolia and Arbuscular Mycorrhiza Fungi for Acid Mine Drainage Phytoremediation}

\author{
AKHMAD HABIBULLAH ${ }^{*}$, NOOR KHAMIDAH ${ }^{* *}$ dan RIZA A. SAPUTRA** \\ Jurusan Agroekoteknologi Fakultas Pertanian Universitas Lambung Mangkurat \\ Jalan Jend. Achmad Yani km. 36 Banjarbaru, Kalimantan Selatan, 70714 \\ e-mail : akhmad.habibullah96@gmail.com \\ * Kontributor utama, ** Kontributor anggota
}

\begin{abstract}
ABSTRAK
Air asam tambang (AAT) adalah air berasal dari tambang atau batuan yang mengandung mineral sulfida yang tersingkap dan teroksidasi akibat dari kegiatan penambangan terbuka. Kandungan sulfat dan logam yang tinggi di dalam air asam tambang mengakibatkan kerusakan lingkungan sehingga diperlukan penanganan khusus. Fitoremediasi dapat digunakan untuk mengatasi permasalahan tersebut sehingga sesuai dengan baku mutu lingkungan air asam tambang. Tujuan penelitian ini ialah untuk mengetahui pengaruh dosis aplikasi fungi mikoriza arbuskular (FMA) terhadap pertumbuhan dan serapan logam tanaman akumulator Typha angustifolia pada air asam tambang. Penelitian ini menggunakan rancangan acak lengkap dengan 4 perlakuan yaitu mo (0 g FMA/ember), m1 (10 g FMA/ember), m2 (12 g FMA/ember), m3 (14 g FMA/ember) dan 4 ulangan, sehingga diperoleh 16 satuan percobaan. Pengamatan yang dilakukan meliputi tinggi tanaman, jumlah anakan, Fe-akar, Mn-akar, Fe-larut, Mnlarut, $\mathrm{pH}$ AAT dan hubungan antar peubah pengamatan. Dosis terbaik dalam meningkatkan pertumbuhan $T$. angustifolia adalah perlakuan $\mathrm{m}_{3}$ (14 g FMA/ember), sedangkan terhadap serapan Fe dan Mn, perlakuan m2 (12 g FMA/ember) dengan nilai indeks fitoremediasi (IFR) Mn dan Fe 98,94\% dan 57,93\% memenuhi standar baku mutu lingkungan.
\end{abstract}

Kata kunci: fitoremediasi, Typha angustifolia, fungi mikoriza arbuskular, air asam tambang.

\begin{abstract}
Acid mine drainage is water originating from mines or rocks containing sulfide minerals which are exposed and oxidized as a result of open-pit mining activities. The high content of sulfates and metals in acid mine drainage causes environmental damage, so special handling is required. Phytoremediation can be used to overcome these problems so that it is in accordance with the environmental quality standards for acid mine drainage. The purpose of this study was to determine the effect of the application dose of arbuscular mycorrhizal fungi (AMF) on the growth and metal uptake of Typha angustifolia accumulator plants in acid mine drainage. This study used a completely randomized design with 4 treatments, namely mo (0 g AMF/bucket), m1 (10 g AMF/bucket), $m_{2}$ (12 g AMF/bucket), $m_{3}$ (14 g AMF/bucket) and 4 replications, so that obtained 16 experimental units. The plant height, number of tillers, root-Fe, root-Mn, soluble-Fe, soluble-Mn, AAT $\mathrm{pH}$ and the relationship between variables were observed. The best dose to increase the growth of $T$. angustifolia was $\mathrm{m}_{3}$ treatment (14 $\mathrm{g}$ AMF/bucket), whereas for Fe and Mn absorption was $m_{2}$ treatment (12 $\mathrm{g}$ AMF/bucket) with index fitoremediation (IFR) $\mathrm{Mn}$ and Fe of $98.94 \%$ and $57.93 \%$ have met environmental quality standards.
\end{abstract}

Keywords: phytoremediation, Typha angustifolia, arbuscular mycorrhiza fungi, acid mine drainage. 


\section{PENDAHULUAN}

Penambangan batubara di Indonesia kebanyakan dilakukan dengan sistem tambang terbuka (open pit). Sistem penambangan ini menyebabkan batuan yang ada pada lokasi penambangan tersingkap ke permukaan, sehingga akan mudah bereaksi dengan udara dan air secara langsung (Kasmiani, Widodo dan Bakri, 2018).

Penambangan dengan menggunakan metode open mining tersebut menghilangkan permukaan tanah dan bahan organik tanah. Hasilnya lapisan batuan yang mengandung sulfur terbuka dan bereaksi dengan air atau oksigen sehingga melepaskan sulfat ke lingkungan (Wahyudin, Widodo dan Nurwaskito, 2018). Reaksi tersebut menyebabkan kemasaman pada tanah dan air. Fenomena ini dikenal juga dengan istilah air asam tambang (AAT) atau acid mine drainage (AMD) (Wahyudin, Widodo dan Nurwaskito, 2018). Mineral sulfida yang teroksidasi akan mengubah sifat kimia secara drastis, seperti rendahnya $\mathrm{pH}$ air $(<4,5)$ dan meningkatnya konsentrasi logam-logam terlarut (Al, Fe, Mn, Cd, $\mathrm{Cu}, \mathrm{Sn}, \mathrm{Zn}, \mathrm{As}$ dan $\mathrm{Hg}$ ) yang dapat membahayakan lingkungan pada konsentrasi tertentu (Yunus dan Prihatini, 2018). Diperkuat oleh Patang (2018) bahwa daya racun logam berat akan sangat ditentukan oleh $\mathrm{pH}$ yang tinggi karena logam berat membentuk senyawa kompleks yang mengendap dalam air. Dampak yang dapat ditimbulkan oleh air asam tambang adalah mengurangi kesuburan tanah, mengganggu kesehatan masyarakat sekitar dan dapat mengakibatkan korosi pada peralatan tambang (Hidayat, 2017).

Salah satu teknik rehabilitasi lingkungan tercemar AAT adalah fitoremediasi. Penggunaan tumbuhan untuk mengurangi, menghilangkan, menurunkan, atau melumpuhkan racun lingkungan bertujuan memulihkan suatu situs ke kondisi yang dapat digunakan lagi (Henny, Satria dan Susanti, 2010). Beberapa jenis tanaman yang berpotensi sebagai hiperakumulator karena mampu menyerap kontaminan adalah eceng gondok, kiambang, dan Typha latifolia (Irhamni $d k k ., 2018)$.

Typha angustifolia merupakan kerabat dari Typha latifolia; tumbuhan air yang mampu meremediasi tanah dan air terkontaminasi. Sulthoni dkk. (2014) melaporkan bahwa tanaman T. latifolia dapat mengakumulasi besi (Fe) dari AAT di dalam reaktor di rumah kaca. Typha latifolia memiliki kemampuan dalam penyerapan logam berat $\mathrm{Cr}, \mathrm{Hg}$, dan $\mathrm{Pb}$ lebih banyak daripada eceng gondok dan kiambang karena memiliki berat kering lebih besar (Irhamni dkk., 2018).

Tanaman T. latifolia juga memiliki banyak bulu akar sehingga luas permukaan akar akan semakin besar dan daya jelajah akar lebih luas (Passioura, 2002; Djazuli, 2016). Upaya yang dapat dilakukan untuk meningkatkan serapan oleh tanaman pada fitoremediasi adalah menggunakan fungi yang bersimbiosis dengan akar tanaman yaitu fungi mikoriza arbuscular (FMA) (Talanca, 2010).

Peran simbiosis FMA terhadap efektivitas fitoremediasi logam berat cukup signifikan. Keberadaan FMA mampu meningkatkan penyerapan logam berat dan berkontribusi pada fitostabilisasi logam berat dalam tanah (Gaur dan Adholeya, 2004; Khan, 2005). Mikoriza juga berperan dalam bioremediasi lahan basah tercemar limbah industri. Contohnya, inokulasi FMA pada tanaman semi akuatik Phragmites australis menurunkan konsentrasi sedimen polutan organik (Oliveira, Dodd dan Castro, 2001). Dawile (2016) juga melaporkan bahwa tanaman fitoremediasi jenis sorgum (Sorghum bicolor L.) yang diinokulasi FMA mampu meningkatkan pertumbuhan panjang akar dan panjang pucuk pada kondisi cekaman $\mathrm{Cr}^{6+}$. Berdasarkan kemampuan tanaman famili Typhaceae (cattails) dan FMA dalam menstabilisasi zat kontaminan, maka dalam penelitian ini perlu digabungkan kemampuan keduanya dalam meremediasi lahan pascatambang agar lebih efektif. Tujuan penelitian ini untuk mengetahui dosis aplikasi FMA terbaik terhadap pertumbuhan dan serapan logam T. angustifolia pada AAT.

\section{METODE}

Penelitian ini dilaksanakan selama dua bulan dari Februari sampai April 2020. Bertempat di Rumah Kaca Jurusan Agroekoteknologi dan Laboratorium Balai Riset dan Standardisasi Industri Banjarbaru, Kalimantan Selatan.

Bahan yang digunakan pada penelitian ini adalah tanah mineral kering $(\mathrm{pH} 7,98$; $\mathrm{BD} 1,29$ 
$\left.\mathrm{g} / \mathrm{cm}^{3}\right)$, Typha angustifolia yang diambil dari lahan rawa di Kecamatan Pengaron Kabupaten Banjar Kalimantan Selatan, air asam tambang (pH 4,40; Fe 1,70 ppm; dan Mn 13,62 ppm), Mychorrhiza powder (FMA label Mycovir) yang mengandung FMA Acaulospora, Gigaspora, Glomus, dan Scutrllospora.

Alat yang digunakan pada penelitian ini adalah ember berukuran $23 \times 19 \mathrm{~cm}$, cangkul, jerigen, pH meter Thermo Scientific Orion Star A221, Spektrofotometer Thermo Scientific Genesys 20, neraca analitik, dan hot plate.

\section{Metode Penelitian}

Percobaan ini menggunakan rancangan acak lengkap yang menguji dosis FMA yang terdiri dari 4 taraf:

$\mathrm{m}_{0}=0 \mathrm{~g}$ FMA/ember (kontrol)

$\mathrm{m}_{1}=10 \mathrm{~g}$ FMA/ember

$\mathrm{m}_{2}=12 \mathrm{~g} \mathrm{FMA/ember}$

$\mathrm{m}_{3}=14 \mathrm{~g}$ FMA/ember

Masing-masing perlakuan diulang sebanyak 4 kali.

\section{Pelaksanaan Penelitian}

Air asam tambang diambil sebanyak $175 \mathrm{~L}$ dengan cara mengambil langsung AAT dari void tambang batubara di PT. Kadya Caraka Mulia, Desa Pengaron, Kabupaten Banjar, Kalimantan Selatan menggunakan jerigen kapasitas $25 \mathrm{~L}$ sejumlah 7 buah.

Air asam tambang yang telah diambil dari void tambang batubara dilakukan pengukuran Felarut (metode spektrofotometer), Mn-larut (metode spektrofotometer), dan $\mathrm{pH}$ AAT $(\mathrm{pH}$ meter elektroda) di laboratorium. Hasil pengukuran ini dijadikan sebagai informasi awal karakteristik kimia AAT (Tabel 1).

Bibit $T$. angustifolia yang digunakan terlebih dahulu diseleksi berdasarkan keseragaman tumbuh (tinggi tanaman antara 30-35 cm), kemudian diaklimatisasi pada media subur selama dua minggu dan ditempatkan di rumah kaca. Media untuk aklimatisasi ditempatkan ke dalam ember berukuran $60 \mathrm{~L}$ sebanyak 2 buah, kemudian $T$. angustifolia dipindah tanam masing-masing 10 tanaman ke dalam 1 ember yang sudah diisi media untuk aklimatisasi.
Tanah mineral kering untuk media tumbuh $T$. angustifolia diaduk hingga homogen, kemudian ditimbang seberat $5 \mathrm{~kg}$ setiap ember. Tanah yang sudah ditimbang, dimasukkan ke dalam ember percobaan berukuran $19 \times 23$ $\mathrm{cm}$. Setelah itu, ember disusun di dalam rumah kaca sesuai dengan bagan tata letak penelitian.

Ember yang sudah diisi media tanah kemudian diberi lubang tanam di bagian tengah ember. Setelah itu, diaplikasikan FMA pada lubang tanam dengan 3 perlakuan $\left(m_{0}=0 \mathrm{~g}\right.$ FMA/ember (kontrol); $\mathrm{m}_{1}=10 \mathrm{~g}$ FMA/ember; $\mathrm{m}_{2}=15 \mathrm{~g}$ FMA/ember; dan $m_{3}=20$ g FMA/ember, kemudian $T$. angustifolia dipindah tanam dari ember aklimatisasi masing-masing 1 batang untuk setiap ember. Penanaman $T$. angustifolia dilakukan sore hari untuk menghindari panas sinar matahari pada waktu siang hari.

Media tumbuh yang sudah ditanami $T$. angustifolia dan diaplikasikan FMA kemudian diberi AAT masing-masing $2 \mathrm{~L}$ untuk setiap ember pada hari pertama, kemudian ditambahkan 2 L AAT setiap 6 hari pada masingmasing tanaman sampai minggu keempat. Desain percobaan fitoremediasi AAT menggunakan $T$. angustifolia yang diaplikasikan FMA dapat dilihat pada Gambar 1.

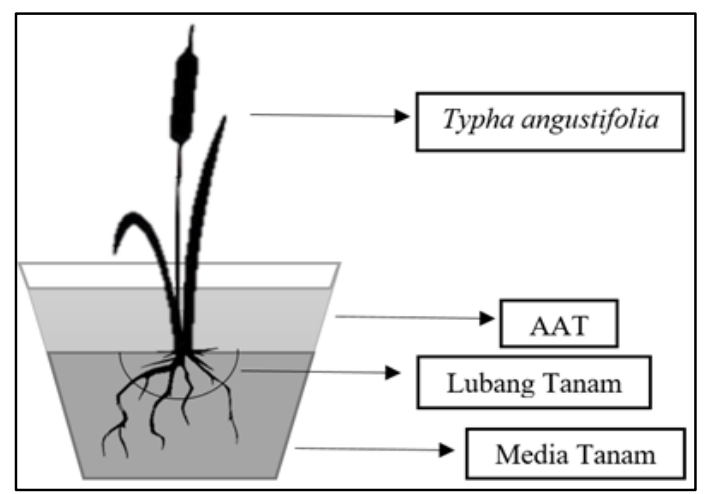

Gambar 1. Desain percobaan fitoremediasi AAT menggunakan T. angustifolia yang diaplikasikan FMA

\section{Pengamatan}

Pengamatan terbagi menjadi empat kelompok yaitu pengamatan pertumbuhan $T$. angustifolia, pengamatan $\mathrm{Fe}, \mathrm{Mn}, \mathrm{pH}$ AAT, pengamatan $\mathrm{Fe}$ dan $\mathrm{Mn}$ akar, dan hubungan antar peubah pengamatan. 
1. Pengamatan pertumbuhan $T$. angustifolia

a. Pertambahan tinggi tanaman. Pengukuran tinggi tanaman dilakukan pada hari pertama dan minggu keempat setelah tanam (MST) dengan cara mengukur tanaman menggunakan penggaris dari pangkal batang sampai ujung daun T. angustifolia. Selisih antara tinggi tanaman minggu keempat dan hari pertama adalah pertambahan tinggi tanaman $T$. angustifolia.

b. Jumlah anakan. Pengukuran jumlah anakan dilakukan pada minggu keempat setelah tanam (MST) dengan cara mengukur jumlah anakan yang tumbuh pada setiap ember.

2. Pengamatan Fe, Mn, dan $\mathrm{pH}$ AAT

a. Pengukuran Fe-larut. Pengukuran Felarut AAT pada setiap perlakuan dilakukan pada minggu keempat setelah tanam (MST) dengan menggunakan metode spektrofotometer.

b. Pengukuran Mn-larut. Pengukuran Mnlarut AAT pada setiap perlakuan dilakukan pada minggu keempat setelah tanam (MST) dengan menggunakan metode spektrofotometer.

c. Perhitungan Indeks Fitoremediasi (IFR). Hasil pengukuran konsentrasi Fe-larut dan Mn-larut yang terkandung pada AAT dikonversi menjadi nilai indeks fitoremediasi (IFR). IFR adalah persentase penurunan konsentrasi parameter awal dibandingkan dengan parameter pada effluent. IFR dihitung dengan rumus berikut (Yunus dan Prihatini, 2018):

$$
\operatorname{IFR}(\%)=\frac{[\text { awal] }-[\text { akhir] }}{\text { [awal] }} \times 100 \%
$$

d. Pengukuran pH AAT. Pengukuran $\mathrm{pH}$ AAT dilakukan setelah aplikasi pada minggu keempat setelah tanam (MST) menggunakan $\mathrm{pH}$ meter elektroda.

3. Pengamatan Fe dan Mn akar

a. Pengukuran Fe akar. Pengukuran Fe akar T. angustifolia dilakukan pada minggu keempat setelah tanam (MST) menggunakan metode spektrofoto-meter.

b. Pengukuran Mn akar. Pengukuran Mn akar T. angustifolia dilakukan pada minggu keempat setelah tanam (MST) menggunakan metode spektrofoto-meter.

4. Hubungan antar peubah pengamatan, didapat dengan cara menghitung menggunakan korelasi, sehingga didapatkan persamaan koefisien korelasi (r).

Rumus korelasi (Muhidin dan Abdurahman, 2017):

$r=\frac{\left(n \times \sum X Y\right)-(X)(Y)}{\sqrt{\left\{\left(n \times \sum X\right)-\left(\sum X\right)^{2}\right\} \times\left\{\left(n \times \sum Y\right)-\left(\sum Y\right)^{2}\right\}}} \ldots \ldots \ldots . . . .(2)$

Keterangan: $\mathrm{n}=$ jumlah; $\mathrm{X}=$ parameter (1);

$\mathrm{Y}=$ parameter (2)

\section{Analisis Statistik}

Homogenitas data hasil pengukuran diuji menggunakan uji Bartlett. Data yang tidak homogen ditransformasi menggunakan transformasi logaritma sebelum dilakukan analisis ragam menggunakan uji F. Apabila hasil analisis ragam berpengaruh nyata atau sangat nyata, maka dilanjutkan dengan uji beda nilai tengah menggunakan LSD $p<0,05$ (David dan Djamaris, 2018).

\section{HASIL DAN PEMBAHASAN}

\section{Hasil}

\section{Karakteristik Kimia Air Asam Tambang}

Sebelum percobaan, AAT mengandung besi (Fe), mangan $(\mathrm{Mn})$ dan kemasaman $(\mathrm{pH})$ masing-masing 1,70 ppm; 13,62 ppm dan, 4,40 (Tabel 1). Kandungan $\mathrm{Mn}$ dan $\mathrm{pH}$ tidak berada dalam batas toleransi baku mutu lingkungan, sehingga harus melalui proses remediasi untuk mencapai batas toleransi sesuai dengan peraturan.

Tabel 1. Hasil uji awal kandungan besi (Fe), mangan (Mn), dan $\mathrm{pH}$ air asam tambang (AAT)

\begin{tabular}{clcc}
\hline No. & Parameter Uji & Satuan & Hasil Uji \\
\hline 1. & Besi (Fe) & ppm & 1,70 \\
2. & Mangan (Mn) & ppm & 13,62 \\
3. & pH AAT & - & 4,40 \\
\hline
\end{tabular}

Menurut Peraturan Daerah Provinsi Kalimantan Selatan No. 36 Tahun 2008 tentang Baku Mutu Limbah Cair batas toleransi kandungan Fe $<7$ ppm, Mn < 4 ppm dan pH AAT 6-9 adalah batas aman kandungan logam di AAT. 


\section{Pertumbuhan $T$. angustifolia}

\section{Pertambahan Tinggi Tanaman}

Hasil analisis ragam menunjukkan pemberian FMA berpengaruh terhadap pertambahan tinggi tanaman $T$. angustifolia umur 4 MST. Pemberian FMA pada perlakuan $\mathrm{m}_{2}(12 \mathrm{~g})$ dan $\mathrm{m}_{3}(14 \mathrm{~g})$ menghasilkan tinggi tanaman yang lebih tinggi bila dibandingkan dengan perlakuan $\mathrm{m}_{1}(10 \mathrm{~g})$, namun tidak berbeda dengan perlakuan mo $(0 \mathrm{~g})$ (Gambar 2).

\section{Jumlah Anakan}

Hasil analisis ragam menunjukkan bahwa pemberian FMA tidak memberikan pengaruh terhadap pertambahan jumlah anakan $T$. angustifolia. Rerata jumlah anakan $T$. angustifolia pada perlakuan mo (kontrol) 1,50 anakan; $m_{1}=10$ g FMA 1,75 anakan; $m_{2}=12$ g FMA 2,25 anakan; dan $m_{3}=2,25$ anakan (Gambar 3).

\section{Besi (Fe), Mangan (Mn), dan pH AAT}

\section{Fe-larut}

Hasil analisis ragam menunjukkan bahwa pemberian FMA tidak berpengaruh terhadap Felarut AAT pada umur tanaman 4 MST. Rerata konsentrasi Fe-larut AAT pada perlakuan mo (kontrol) 0,98 ppm; $\mathrm{m}_{1}=10 \mathrm{~g}$ FMA 0,95 ppm; $\mathrm{m}_{2}=12$ g FMA 0,72 ppm; dan $\mathrm{m}_{3}=14 \mathrm{~g} \mathrm{FMA}$ 1,01 ppm. Rerata Fe-larut AAT disajikan pada Gambar 4.

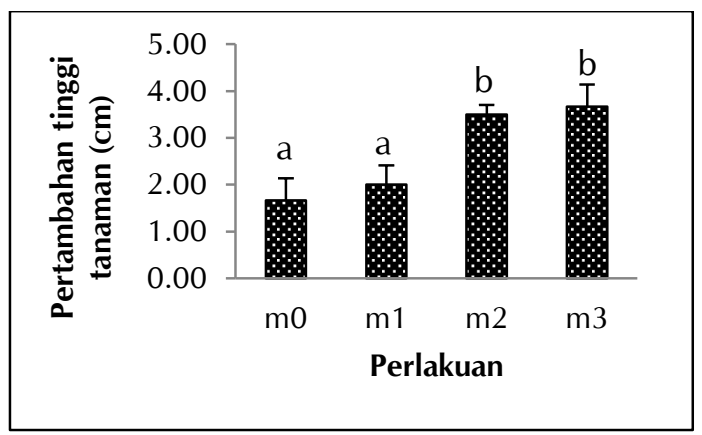

Keterangan: $m_{0}=0 \mathrm{~g}$ FMA/ember (kontrol); $m_{1}=10 \mathrm{~g}$ FMA/ember; $m_{2}=12$ g FMA/ember; $m_{3}=14$ g FMA/ember

Gambar 2. Pertambahan tinggi tanaman $T$. angustifolia saat umur 4 MST yang diaplikasikan FMA

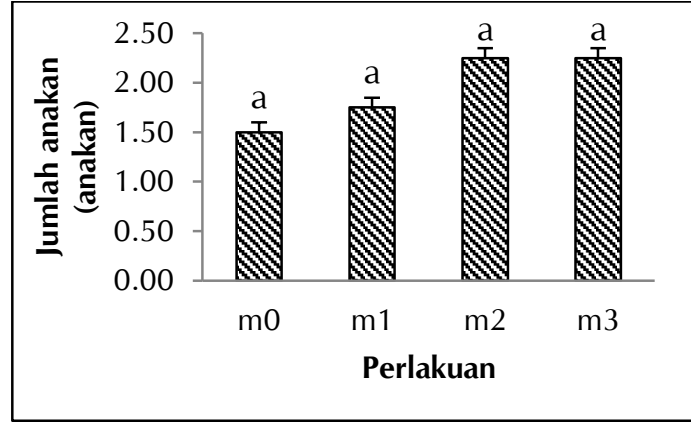

Keterangan: $m_{0}=0 \mathrm{~g}$ FMA/ember (kontrol); $m_{1}=10 \mathrm{~g}$ FMA/ember; $m_{2}=12$ g FMA/ember; $m_{3}=14$ g FMA/ember

Gambar 3. Jumlah anakan T. angustifolia saat umur 4 MST yang diaplikasikan FMA

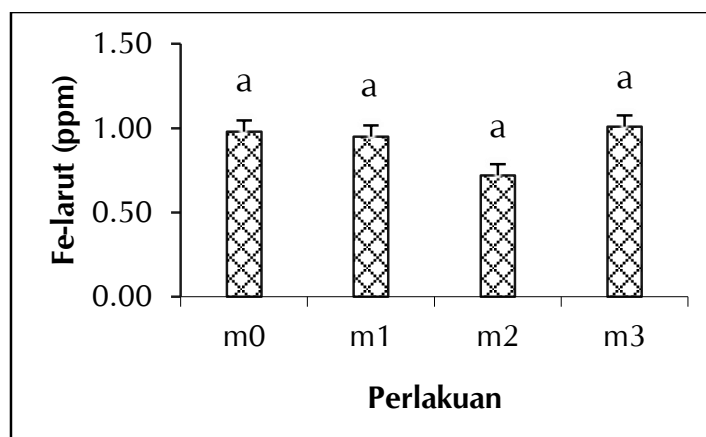

Keterangan: $m_{0}=0 \mathrm{~g}$ FMA/ember (kontrol); $m_{1}=10 \mathrm{~g}$ FMA/ember; $m_{2}=12$ g FMA/ember; $m_{3}=14$ g FMA/ember

Gambar 4. Fe-larut AAT saat umur tanaman 4 MST yang diaplikasikan FMA

* Garis di atas diagram batang merupakan standard error dari perlakuan $(n=4)$. Huruf yang sama di atas garis menunjukkan bahwa perlakuan memberikan pengaruh yang tidak berbeda berdasarkan LSD $p<0,05$.

\section{Mn-larut}

Hasil analisis ragam menunjukkan bahwa pemberian FMA tidak berpengaruh terhadap Mn-larut AAT pada umur tanaman $4 \mathrm{MST}$. Rerata konsentrasi Mn-larut AAT pada perlakuan $\mathrm{m}_{0}$ (kontrol) 0,16 ppm; $\mathrm{m}_{1}=10 \mathrm{~g}$ FMA 0,22 ppm; $\mathrm{m}_{2}=12 \mathrm{~g}$ FMA 0,14 ppm; dan $\mathrm{m}_{3}=14 \mathrm{~g}$ FMA 0,15 ppm. Rerata kadar Mnlarut AAT disajikan pada Gambar 5. 


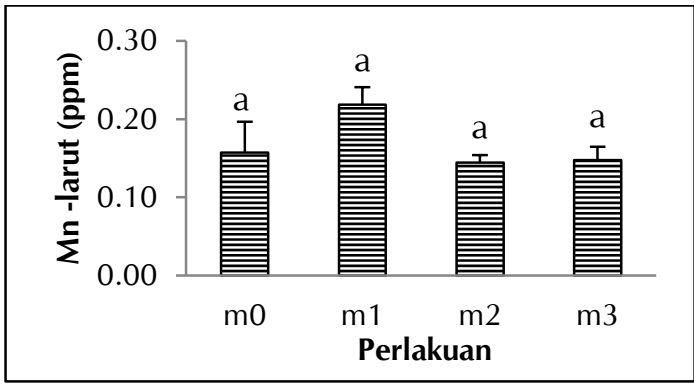

Keterangan: $\mathrm{m}_{0}=0 \mathrm{~g}$ FMA/ember (kontrol); $\mathrm{m}_{1}=10 \mathrm{~g}$ FMA/ember; $m_{2}=12 \mathrm{~g} \mathrm{FMA/ember;} \mathrm{m}_{3}=14$ g FMA/ember

Gambar 5. Mn-larut AAT saat umur tanaman 4 MST yang diaplikasikan FMA

pH AAT

Hasil analisis ragam menunjukkan bahwa pemberian FMA tidak berpengaruh terhadap kenaikan pH AAT pada umur tanaman 4 MST. Rerata nilai $\mathrm{pH}$ AAT pada perlakuan mo (kontrol) 7,29; $\mathrm{m}_{1}=10 \mathrm{~g}$ FMA 7,67; $\mathrm{m}_{2}=12 \mathrm{~g}$ FMA 7,59; dan $m_{3}=14$ g FMA 7,45. Rerata nilai pH AAT disajikan pada Gambar 6 .

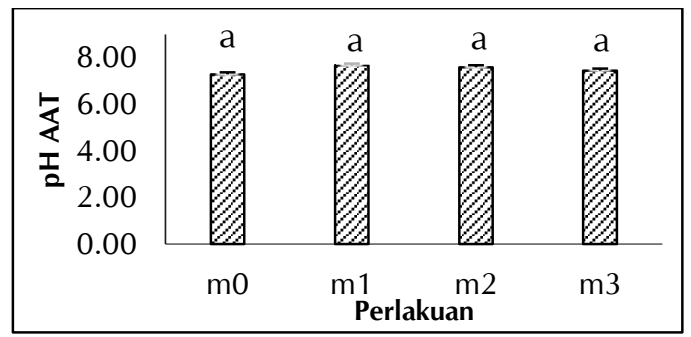

Keterangan: $\mathrm{m}_{0}=0 \mathrm{~g}$ FMA/ember (kontrol); $\mathrm{m}_{1}=10 \mathrm{~g}$ FMA/ember; $m_{2}=12$ g FMA/ember; $m_{3}=$ 14 g FMA/ember

Gambar 6. Nilai pH AAT saat umur tanaman 4 MST yang diaplikasikan FMA

\section{Besi (Fe) dan Mangan (Mn) Akar}

\section{Fe-akar}

Hasil analisis ragam menunjukkan bahwa pemberian FMA berpengaruh terhadap Fe-akar pada umur tanaman 4 MST. Perlakuan $\mathrm{m}_{3}(14 \mathrm{~g})$ berbeda nyata terhadap mo (kontrol), sedangkan perlakuan $\mathrm{m}_{1}(10 \mathrm{~g})$ dan $\mathrm{m}_{2}(12 \mathrm{~g})$ tidak berbeda terhadap kontrol. Pada perlakuan $m_{0}, m_{1}$, dan $\mathrm{m}_{2}$ memiliki serapan lebih tinggi daripada $\mathrm{m}_{3}$. Rerata kadar Fe-akar disajikan pada Gambar 7.

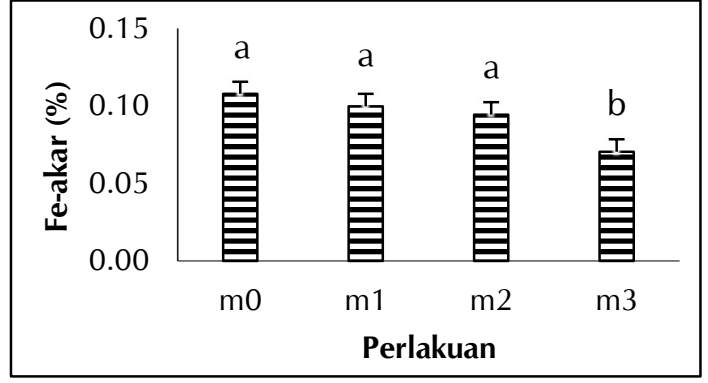

Keterangan: $m_{0}=0 \mathrm{~g}$ FMA/ember (kontrol); $m_{1}=10 \mathrm{~g}$ FMA/ember; $m_{2}=12$ g FMA/ember; $m_{3}=14$ g FMA/ember

Gambar 7. Fe-akar saat umur tanaman 4 MST yang diaplikasikan FMA

\section{Mn-akar}

Hasil analisis ragam menunjukkan bahwa pemberian FMA berpengaruh terhadap Mn-akar pada umur tanaman 4 MST. Perlakuan $\mathrm{m}_{1}(10 \mathrm{~g})$ dan $\mathrm{m}_{3}(14 \mathrm{~g})$ berbeda nyata terhadap kontrol $\left(\mathrm{m}_{0}\right)$, sedangkan pada perlakuan $\mathrm{m}_{2}(12 \mathrm{~g})$ tidak berbeda nyata terhadap $m_{0}, m_{1}$, dan $m_{3}$. Perlakuan mo dan $\mathrm{m}_{2}$ memiliki serapan $\mathrm{Mn}$ akar yang lebih tinggi daripada $m_{1}$ dan $m_{3}$. Rerata kadar Mn-akar disajikan pada Gambar 8.

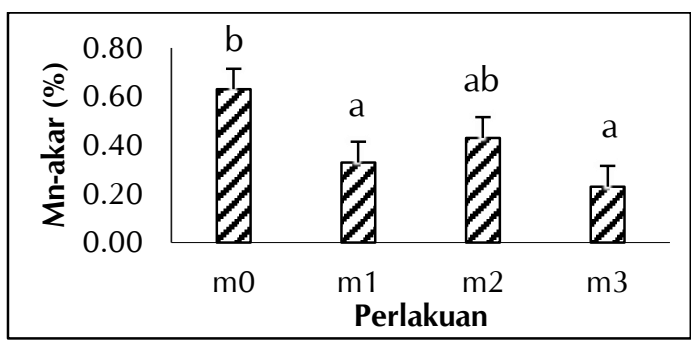

Keterangan: $\mathrm{m}_{0}=0 \mathrm{~g}$ FMA/ember (kontrol); $\mathrm{m}_{1}=10 \mathrm{~g}$ FMA/ember; $m_{2}=12$ g FMA/ember; $m_{3}=14$ g FMA/ember

Gambar 8. Mn-akar saat umur tanaman 4 MST yang diaplikasikan FMA

* Garis di atas diagram batang merupakan standard error dari perlakuan $(n=4)$. Huruf yang sama di atas garis menunjukkan bahwa perlakuan memberikan pengaruh yang tidak berbeda berdasarkan LSD $p<0,05$.

\section{Indeks Fitoremediasi}

Indeks fitoremediasi diperoleh dari hasil perhitungan konsentrasi Fe-larut dan Mn-larut, dan persentase penurunan konsentrasi 
parameter awal dibandingkan dengan parameter pada effluent, dapat dilihat pada Gambar 9-10.

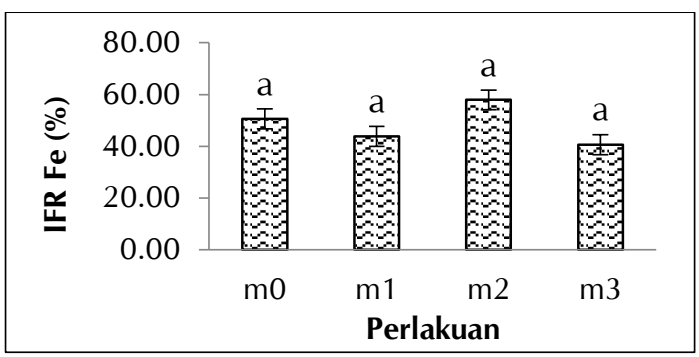

Keterangan: $\mathrm{m}_{0}=0 \mathrm{~g}$ FMA/ember (kontrol); $\mathrm{m}_{1}=10 \mathrm{~g}$ FMA/ember; $m_{2}=12$ g FMA/ember; $m_{3}=14$ g FMA/ember

Gambar 9. Indeks fitoremediasi Fe saat umur tanaman 4 MST yang diaplikasikan FMA

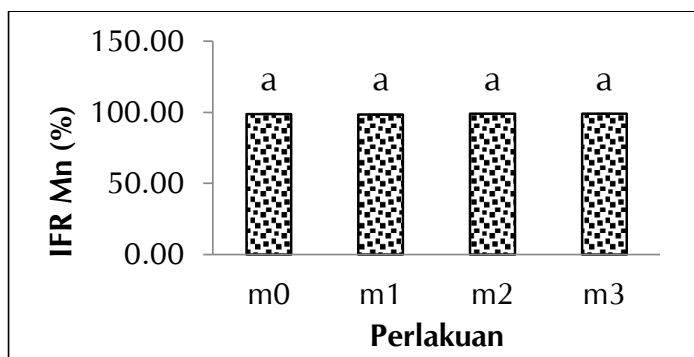

Keterangan: $\mathrm{m}_{0}=0 \mathrm{~g}$ FMA/ember (kontrol); $\mathrm{m}_{1}=10 \mathrm{~g}$ FMA/ember; $m_{2}=12$ g FMA/ember; $m_{3}=14$ g FMA/ember

Gambar 10. Indeks fitoremediasi Mn saat umur tanaman 4 MST yang diaplikasikan FMA

* Garis di atas diagram batang merupakan standard error dari perlakuan $(n=4)$. Huruf yang sama di atas garis menunjukkan bahwa perlakuan memberikan pengaruh yang tidak berbeda berdasarkan LSD $\mathrm{p}<0,05$.

\section{Hubungan Antar Peubah Pengamatan}

Penentuan tingkat keeratan antar peubah pengamatan dilakukan menggunakan uji korelasi untuk mengetahui hubungan antar variabel bersifat independen antara satu dengan yang lainnya (berdiri sendiri dan tidak bergantung satu sama lain) atau memiliki hubungan antar dua variabel. Hasil perhitungan korelasi antar peubah pengamatan dapat dilihat pada Tabel 2.

Tabel 2 menunjukkan hubungan antara peubah pengamatan dengan nilai koefisien korelasi positif (korelasi searah) berturut-turut yaitu Fe akar dengan Mn-akar (korelasi sangat kuat), jumlah anakan dengan tinggi tanaman (kolerasi cukup), jumlah anakan dengan Fe-larut (korelasi cukup), jumlah anakan dengan IFR Mn-larut (korelasi cukup), jumlah anakan dengan Fe-akar (korelasi cukup), jumlah anakan dengan Mn-akar (korelasi cukup), Fe-larut dengan Mn-larut (korelasi cukup), Fe-larut dengan pH AAT (korelasi cukup), IFR Fe-larut dengan IFR Mn-larut (korelasi cukup), IFR Fe-larut dengan Fe-akar (korelasi cukup), IFR Fe-larut dengan Mn-akar (korelasi cukup), tinggi tanaman dengan Fe-larut (korelasi sangat lemah), tinggi tanaman dengan IFR M-larut korelasi sagat lemah), Mn-larut dengan Fe-akar (korelasi sangat lemah), dan IFR Mn-larut dengan Mn-akar (korelasi sangat lemah).

Tabel 2. Hubungan antar peubah pengamatan

\begin{tabular}{|c|c|c|c|c|c|c|c|c|c|}
\hline & $\begin{array}{l}\text { Pertambahan } \\
\text { tinggi tanaman }\end{array}$ & $\begin{array}{l}\text { Jumlah } \\
\text { anakan }\end{array}$ & Fe-larut & $\begin{array}{l}\text { Mn- } \\
\text { larut }\end{array}$ & $\mathrm{pH}$ AAT & IFR Fe & IFR Mn & Fe-akar & $\begin{array}{l}\text { Mn- } \\
\text { akar }\end{array}$ \\
\hline \multicolumn{10}{|l|}{$\begin{array}{l}\text { Pertambahan } \\
\text { tinggi tanaman }\end{array}$} \\
\hline Jumlah anakan & 0,398 & & & & & & & & \\
\hline Fe-larut & 0,199 & 0,300 & & & & & & & \\
\hline Mn-larut & $-0,008$ & $-0,285$ & 0,487 & & & & & & \\
\hline pH AAT & $-0,562$ & $-0,260$ & 0,268 & 0,416 & & & & & \\
\hline IFR Fe & $-0,199$ & $-0,300$ & $-1,000$ & $-0,487$ & $-0,268$ & & & & \\
\hline IFR Mn & 0,008 & 0,285 & $-0,487$ & $-1,000$ & $-0,416$ & 0,487 & & & \\
\hline Fe-akar & $-0,497$ & $-0,427$ & $-0,366$ & 0,144 & 0,342 & 0,366 & $-0,114$ & & \\
\hline Mn-akar & $-0,394$ & $-0,452$ & $-0,411$ & $-0,060$ & 0,299 & 0,411 & 0,060 & 0,776 & \\
\hline
\end{tabular}

Keterangan: Jika nilai koefisien korelasi (r) positif, maka hubungan kedua variabel erat. Sebaliknya jika nilai koefisien korelasi (r) negatif, maka hubungan kedua variabel tidak erat. Kriteria nilai keeratan hubungan (Sarwono, 2006) terbagi atas: $0=$ tidak ada korelasi antar dua variabel; $>0-0,25=$ korelasi sangat lemah; $>0,25-0,5=$ korelasi cukup; $>0,5-0,75=$ korelasi kuat; $>0,75-0,99=$ korelasi sangat kuat; dan $1=$ korelasi sempurna. 
Hubungan antara peubah pengamatan dengan nilai koefisien korelasi negatif (korelasi tidak erat) berturut-turut yaitu tinggi tanaman dengan Fe-akar, tinggi tanaman dengan Mn-akar, jumlah anakan dengan Mn-larut, jumlah anakan dengan pH AAT, jumlah anakan dengan IFR Fe-larut, tinggi tanaman dengan Mn-larut, tinggi tanaman dengan IFR Fe-larut, Mn-larut dengan Mn-akar, IFR Mn-larut dengan Fe-akar, tinggi tanaman dengan $\mathrm{pH}$ AAT, dan Fe-larut dengan IFR Fe-larut (Tabel 2).

\section{PEMBAHASAN}

\section{Pertumbuhan $T$. angustifolia}

Perlakuan FMA berpengaruh terhadap tinggi tanaman (Gambar 2). Pemberian FMA lebih meningkatkan tinggi tanaman dibandingkan tanpa pemberian FMA. Hal ini diduga karena FMA dapat memperbanyak bulu akar, sehingga akar semakin mampu menyerap unsur hara. Dewi (2007) menyatakan peran mikoriza adalah membantu penyerapan unsur hara tanaman, peningkatan pertumbuhan dan hasil produk tanaman. Selain itu, FMA juga mampu membantu tanaman dalam menstabilisasi pada kondisi tercekam atau tercemar sehingga tanaman yang diberikan FMA lebih tinggi daripada kontrol. Hal ini sesuai dengan Smith dan Read (2008) serta Garg dan Chandel (2010) yang menyatakan mikoriza mampu membantu mempertahankan stabilitas pertumbuhan tanaman pada kondisi tercemar.

Tidak berpengaruhnya perlakuan FMA terhadap jumlah anakan (Gambar 3) diduga karena akar tanaman T. angustifolia mampu beradaptasi dengan lingkungan, sehingga akar tanaman tetap mampu menyerap unsur hara di dalam tanah meskipun dalam keadaan tercekam. Diperkuat oleh Rungkat (2009), yang menyatakan tanaman yang bermikoriza biasanya tumbuh lebih baik daripada tanaman yang tidak bermikoriza. Mikoriza memiliki peranan bagi pertumbuhan dan produksi tanaman sebagai berikut: a) meningkatkan penyerapan unsur hara, b) melindungi tanaman inang dari pengaruh luar yang merusak, c) cepat beradaptasi dalam kondisi tanah yang terkontaminan, d) melindungi tanaman dari patogen akar, e) memperbaiki produktivitas tanah.

\section{Besi (Fe), Mangan (Mn), dan pH AAT}

Perlakuan FMA tidak berpengaruh terhadap kadar Fe-larut dan Mn-larut (Gambar 4 dan 5). Tidak berpengaruhnya perlakuan FMA terhadap kadar Fe dan Mn-larut karena penelitian ini hanya dilakukan selama 4 minggu. Sependapat dengan Madaniyah (2016) yang menyatakan bahwa penurunan Fe dan Mn-larut yang paling signifikan mulai terlihat pada 29 hari setelah tanam. Lamanya genangan air mengakibatkan lingkungan di bawah tanaman menjadi anaerob, sehingga konsentrasi $\mathrm{CO}_{2}$ air juga memengaruhi nilai $\mathrm{pH}, \mathrm{Fe}$, dan Mn-larut.

Tidak berpengaruhnya perlakuan FMA terhadap kadar Fe-larut juga diduga oleh adanya peran mikroba lain selain FMA yang terdapat di dalam tanah. Mikroba ini berpengaruh terhadap nilai $\mathrm{pH}$ dan berkorelasi terhadap kandungan Fe-larut pada air. Diperkuat oleh Chang, Shin dan Kim (2000) dan Gibert dkk. (2005) yang menyatakan bahwa pada sistem wetland anaerobik, komposisi matrik yang digunakan seperti kompos yang ditambahkan dan lumpur aktif dari sewage dapat menstimulasi pertumbuhan mikroba, sehingga nilai pH AAT pada semua perlakuan menjadi meningkat (Gambar 6) dibandingkan sebelum diberi perlakuan FMA (Tabel 1). Hal ini menyebabkan berkorelasinya nilai $\mathrm{pH}$ dengan konsentrasi Fe-larut. Sependapat dengan Madaniyah (2016) yang menyatakan fenomena meningkatnya kembali konsentrasi Fe dan Mn pada bagian permukaan lahan basah disebabkan oleh proses oksidasi biotik, abiotik, maupun foto-oksidasi logam sulfida yang telah terbentuk pada permukaan lahan basah tersebut, sehingga nilai $\mathrm{pH}$ AAT menjadi meningkat.

Madaniyah (2016) juga melaporkan terjadinya kenaikan dan penurunan logam Fe dan Mn terlarut pada sistem wetland dapat disebabkan oleh beberapa kemungkinan, yaitu: interaksi antara sulfida yang dihasilkan pada proses reduksi sulfat dengan logam bervalensi 2 (seperti $\mathrm{Fe}^{2+}$ dan $\mathrm{Mn}^{2+}$ ) membentuk logam sulfida yang mengendap; proses absorpsi logam oleh jaringan tanaman; proses adsorpsi logam oleh bahan organik; dan proses biosorpsi logam oleh mikroorganisme yang terdapat pada lingkungan lahan basah. 
Perlakuan FMA tidak menurunkan konsentrasi Fe dan Mn-larut dibandingkan dengan kontrol, tetapi perlakuan $\mathrm{m}_{2}(12 \mathrm{~g} \quad \mathrm{FMA} / \mathrm{ember})$ berpotensi menurunkan konsentrasi Fe dan Mn-larut (Gambar 4 dan 5). Penurunan ini sejalan dengan Chen $d k k$. (2007) yang menyatakan bahwa tanaman tanpa aplikasi mikoriza mengimobilisasi logam berat lebih rendah dibandingkan tanaman dengan aplikasi mikoriza.

Hasil analisis ragam perlakuan FMA tidak berpengaruh terhadap nilai pH AAT (Gambar 6). Tidak berpengaruhnya perlakuan FMA terhadap nilai $\mathrm{pH}$ AAT diduga karena adanya faktor lain selain FMA, berupa lingkungan dan pengaruh biologis, yang meliputi pengaruh dari media tanam, lingkungan yang tergenang (anaerob) dan pengaruh biologis (mikroba) pada lingkungan, sehingga nilai pH AAT dapat meningkat. Sejalan dengan Chang, Shin dan Kim (2000) dan Gibert dkk. (2005) yang menyatakan bahwa komposisi matrik yang digunakan seperti pupuk organik yang ditambahkan dan lumpur aktif dari sewage pada sistem wetland anaerobik, mampu menstimulasi pertumbuhan mikroba pereduksi sulfat dan mikroba ini mampu menaikkan alkalinitas yang dapat meningkatkan pH AAT. Sependapat dengan Henny, Satria dan Susanti (2010) yang menyatakan bahwa peningkatan $\mathrm{pH}$ pada perlakuan dikarenakan proses biologi yang terjadi pada interaksi tanaman dengan lingkungannya. Kenaikan $\mathrm{pH}$ AAT juga dipengaruhi oleh $\mathrm{pH}$ media tanam yang digunakan pada penelitian ini, yaitu $\mathrm{pH}$ tanah tergolong agak alkalis dengan nilai $\mathrm{pH}$ 7,98.

Walaupun perlakuan FMA tidak berpengaruh terhadap nilai $\mathrm{pH}$ AAT, namun nilai $\mathrm{pH}$ pada setiap perlakuan mengalami kenaikan $(>7)$ dan nilai pH AAT semua perlakuan cenderung meningkat dibandingkan $\mathrm{pH}$ awal AAT sebelum perlakuan yaitu 4,40 (Tabel 1). Hal ini sejalan dengan Widyatmoko (2011) yang menyatakan semakin tinggi $\mathrm{pH}$, semakin menurun mobilitas logam berat. Amalina, Salimin dan Sudarno (2015) juga mengungkapkan bahwa meningkatnya $\mathrm{pH}$ larutan menjadi basa dapat menurunkan konsentrasi logam berat. Ketika dilakukan penambahan kaustik pada air limbah yang mengandung logam berat, maka logam berat akan bereaksi dengan ion hidroksida sehingga membentuk padatan logam hidroksida.

\section{Besi (Fe) dan Mangan (Mn) Akar}

Perlakuan FMA berpengaruh terhadap kadar Fe-akar dan Mn-akar (Gambar 7 dan 8). Perlakuan FMA dengan dosis $14 \mathrm{~g}$ FMA/ember (m) mampu menurunkan serapan Fe-akar, sedangkan penurunan Mn-akar terdapat pada perlakuan $10 \mathrm{~g}$ FMA/ember $\left(\mathrm{m}_{1}\right)$. Hal ini diduga karena FMA mampu menahan kontaminan pada akar agar tidak terserap oleh tumbuhan. Besi (Fe) dan Mn pada tanaman fitoremediasi mungkin ditranslokasikan ke bagian atas batang. FMA dapat menahan kontaminan (adsorpsi) dengan cara menjerap kontaminan pada permukaan akar tanaman membentuk suatu lapisan tipis atau film pada permukaannya (Khan, 2005). Hal ini juga sejalan dengan pendapat Gaur dan Adholeya (2004) serta Khan (2005) yang mengamati bahwa FMA mampu meningkatkan penyerapan logam berat dan mampu berkontribusi pada imobilisasi logam berat dalam tanah (fitostabilisasi). Fitostabilisasi adalah kemampuan dalam mengekresikan (mengeluarkan) suatu zat kontaminan tertentu untuk mengimobilisasi logam berat di area rizosfer (perakaran), sehingga kontaminan menempel erat pada area perakaran dan sangat sukar terserap ke dalam tanaman (Ghosh dan Singh, 2005).

\section{Indeks Fitoremediasi}

Hasil pengukuran konsentrasi Fe-larut dan Mnlarut yang terkandung pada AAT dikonversi menjadi nilai indeks fitoremediasi (IFR), yaitu persentase penurunan konsentrasi awal logam dibandingkan dengan konsentrasi logam pada effluent.

Perlakuan FMA tidak berpengaruh terhadap IFR Fe dan Mn (Gambar 9 dan 10). Namun, persentase penurunan konsentrasi Fe-larut parameter awal dibandingkan dengan parameter pada effluent pada perlakuan $\mathrm{m}_{2}$ $(57,93 \%)$ lebih tinggi daripada kontrol $\mathrm{m}_{1}$ $(50,54 \%)$. Persentase penurunan konsentrasi Mn-larut parameter awal dibandingkan dengan parameter pada effluent memiliki nilai $>90 \%$ pada masing-masing perlakuan. Perlakuan yang memiliki persentase IFR Mn-larut tertinggi adalah 12 g FMA/ember (98,94\%) dan $14 \mathrm{~g}$ FMA/ember $(98,92 \%)$ sedikit lebih besar daripada kontrol/ 0 g FMA/ember (98,84\%). 


\section{KESIMPULAN DAN SARAN}

\section{Kesimpulan}

Aplikasi FMA dengan dosis 12 g/ember $\left(\mathrm{m}_{2}\right)$ bermanfaat memperbaiki pertumbuhan tinggi tanaman T. angustifolia sebesar $52,28 \%$ dibandingkan dengan perlakuan kontrol (mo), dan menyerap logam berat yang dibuktikan oleh serapan Mn-akar sebesar 46,51\% dan Feakar sebesar 22,22\% dibandingkan dengan perlakuan 14 g/ember $\left(\mathrm{m}_{3}\right)$, sehingga mempunyai potensi yang cukup baik untuk diaplikasikan di lahan tambang dalam mengelola air asam tambang.

\section{Saran}

Sebaiknya untuk penelitian selanjutnya perlu dilakukan analisis kandungan $\mathrm{Fe}$ dan $\mathrm{Mn}$ jaringan selain akar, mengukur tinggi genangan, dan memodifikasi lingkungan dalam kondisi yang mengalir.

\section{UCAPAN TERIMA KASIH}

Terima kasih disampaikan kepada Balai Riset dan Standardisasi Industri Banjarbaru, Kalimantan Selatan yang telah mengizinkan penulis untuk melakukan penelitian di Laboratorium Baristand.

\section{DAFTAR PUSTAKA}

Amalina, Y. N., Salimin, Z. dan Sudarno (2015) "Pengaruh pH dan waktu proses dalam penyisihan logam berat dalam air limbah industri elektroplating dengan proses oksidasi biokimia," Teknik Lingkungan, 4(3), hal. 1-9.

Chang, I., Shin, P. K. dan Kim, B. H. (2000) "Biological treatment of acid mine drainage under sulphate-reducing conditions with solid waste materials as substrate," Water Research, 34(4), hal. 1269-1277. doi: 10.1016/S00431354(99)00268-7.

Chen, B. D., Zhu, Y.-G., Duan, J., Xiao, X. Y. dan Smith, S. E. (2007) "Effects of the arbuscular mycorrhizal fungus Glomus mosseae on growth and metal uptake by four plant species in copper mine tailings," Environmental Pollution, 147(2), hal. 374-380.

doi: 10.1016/j.envpol.2006.04.027.
David, W. dan Djamaris, A. R. (2018) Metode statistik untuk ilmu dan teknologi pangan. First Edit. Jakarta: Penerbitan Universitas Bakrie.

Dawile, F. (2016) Pengaruh pemberian mikoriza Glomus mossae terhadap perkecambahan biji Sorgum (Sorgum bicolor (L.) Moench) kultivar UPCA pada kondisi cekaman krom heksavalen. Universitas Kristen Satya Wacana. Tersedia pada: http://repository.uksw.edu/handle/123456789 /10323.

Dewi, I. R. (2007) Peran, prospek dan kendala dalam pemanfaatan endomikoriza. Bandung.

Djazuli, M. (2016) “Pengaruh cekaman kekeringan terhadap pertumbuhan dan beberapa karakter morfo-fisiologis tanaman nilam," Buletin Penelitian Tanaman Rempah dan Obat, 21(1), hal. 8-17. doi: 10.21082/bullittro.v21n1.2010.\%p.

Garg, N. dan Chandel, S. (2010) "Arbuscular mycorrhizal networks: process and functions. A review," Agronomy for Sustainable Development, 30(3), hal. 581-599. doi: 10.1051/agro/2009054.

Gaur, A. dan Adholeya, A. (2004) "Prospects of arbuscular mycorrhizal fungi in phytoremediation of heavy metal contaminated soils," Current Science, 86(4), hal. 528-534.

Ghosh, M. dan Singh, S. P. (2005) "A review on phytoremediation of heavy metals and utilization of its byproducts," Applied Ecology and Environmental Research, 3(1), hal. 1-18. doi: 10.15666/aeer/0301_001018.

Gibert, O., de Pablo, J., Cortina, J. L. dan Ayora, C. (2005) "Municipal compost-based mixture for acid mine drainage bioremediation: Metal retention mechanisms," Applied Geochemistry, 20(9), hal. 1648-1657. doi: 10.1016/j.apgeochem.2005.04.012.

Henny, C., Satria, G. A. dan Susanti, E. (2010) "Pengolahan air asam tambang menggunakan sistem 'passive treatment,'" in Seminar Nasional Limnologi V. Bogor: LIPI, hal. 331343

Hidayat, L. (2017) "Pengelolaan lingkungan areal tambang batubara (Studi kasus pengelolaan air asam tambang (acid mining drainage) di PT. Bhumi Rantau Energi Kabupaten Tapin Kalimantan Selatan)," Jurnal Penelitian dan Pengembangan IImu Administrasi dan Humaniora, 7(1), hal. 44-52. 
Irhamni, Pandia, S., Purba, E. dan Hasan, W. (2018) "Analisis limbah tumbuhan fitoremediasi (Typha latifolia, eceng gondok, Kiambang) dalam menyerap logam berat," Jurnal Serambi Engineering, 3(2), hal. 344-351.

Kasmiani, Widodo, S. dan Bakri, H. (2018) "Analisis potensi air asam tambang pada batuan pengapit batubara di Salopuru berdasarkan karakteristik geokimia," Jurnal Geomine, 6(3), hal. 138-143.

Khan, A. G. (2005) "Role of soil microbes in the rhizospheres of plants growing on trace metal contaminated soils in phytoremediation," Journal of Trace Elements in Medicine and Biology, 18(4), hal. 355-364.

doi: 10.1016/j.jtemb.2005.02.006.

Madaniyah (2016) Efektivitas tanaman air dalam pembersihan logam berat pada air asam tambang. Institut Pertanian Bogor. Tersedia pada:

https://repository.ipb.ac.id/handle/123456789 $/ 80097$ ? show $=$ full.

Muhidin, S. A. dan Abdurahman, M. (2017) Analisis korelasi, regresi, dan jalur dalam penelitian. 3rd Ed. Bandung: Pustaka Setia.

Oliveira, R. S., Dodd, J. C. dan Castro, P. M. L. (2001) "The mycorrhizal status of phragmites australis in several polluted soils and sediments of an industrialised region of Northern Portugal," Mycorrhiza, 10(5), hal. 241-247. doi: 10.1007/s005720000087.

Passioura, J. B. (2002) "Soil conditions and plant growth," Plant, Cell \& Environment, 25(2), hal. 311-318. doi: 10.1046/j.00168025.2001.00802.x.

Patang (2018) Dampak logam berat kadmium dan timbal pada perairan. Makassar: Badan Penerbit Universitas Negeri Makassar.
Rungkat, J. A. (2009) "Peranan MVA dalam meningkatkan pertumbuhan dan produksi tanaman," Jurnal Formas, 2(4), hal. 270-276.

Sarwono, J. (2006) Metode penelitian kuantitatif dan kualitatif. First Edit. Yogyakarta: Graha Ilmu.

Smith, S. dan Read, D. (2008) Mycorrhizal symbiosis. Third Edit, Mycorrhizal Symbiosis. Third Edit. New York: Academic Press. doi: 10.1016/B978-0-12-370526-6.X5001-6.

Sulthoni, M., Badruzsaufari, Yusran, F. dan Pujawati, Eni, D. (2014) "Kemampuan tanaman ekor kucing (Typha latifolia) dan purun tikus (Eleocharis dulcis) dalam penurunan konsentrasi Fe dan Mn dari air limbah PIT Barat Pamapersada Nusantara Distrik KCMB Kabupaten Banjar," EnviroScienteae, 10(2), hal. 80-87.

Talanca, A. H. (2010) "Status cendawan mikoriza vesikular-arbuskular (MVA) pada tanaman," in Prosiding Pekan Serelia Nasional, hal. 353-357.

Wahyudin, I., Widodo, S. dan Nurwaskito, A. (2018) "Analisis penanganan air asam tambang batubara," Jurnal Geomine, 6(2), hal. 85-89.

Widyatmoko, H. (2011) "Akurasi pH sebagai parameter tingkat pencemaran logam berat dalam tanah," Indonesian Journal of Urban and Environmental Technology, 5(5), hal. 173-178. doi: 10.25105/urbanenvirotech.v5i5.689.

Yunus, R. dan Prihatini, N. S. (2018) "Fitoremediasi Fe dan Mn air asam tambang batubara dengan eceng gondok (Eichornia crassipes) dan purun tikus (Eleocharis dulcis) pada sistem LBB di PT. JBG Kalimantan Selatan," Sainsmat: Jurnal IImiah Ilmu Pengetahuan Alam, 7(1), hal. 7385. 
